\title{
Ethnobotanical Study of Medicinal Plants Used To Treat Livestock Ailments In Ensaro District, North Shewa Zone, Amhara Region, Ethiopia
}

\author{
Asaye Asfaw ( $\sim$ leulasaye@yahoo.com ) \\ Debre Brehan University \\ Ermias Lulekal \\ Addis Ababa University \\ Tamrat Bekele \\ Addis Ababa University \\ Asfaw Debella \\ Ethiopian Public Health Institute \\ Eyob Debebe \\ Ethiopian Public Health Institute \\ Bihonegn Ssisay \\ Ethiopian Public Health Institute
}

\section{Research Article}

Keywords: Ethiopia, Ethnoveterinary medicine, livestock diseases, indigenous knowledge

Posted Date: August 17th, 2021

DOI: https://doi.org/10.21203/rs.3.rs-733200/v1

License: (c) (i) This work is licensed under a Creative Commons Attribution 4.0 International License. Read Full License 


\section{Abstract}

Introduction: In Ethiopia, the majority of animal owners throughout the country depend on traditional healthcare practices to manage their animals' health. Ethnoveterinary practices play significantly greater roles in livestock health care as an alternative or integral part of modern veterinary practices. This is because traditional medicines have remained the most economically affordable and easily available form of therapies for resource-poor communities. Even although, ethnoveterinary medicine is the most important and has higher acceptance and trust by the community in Ethiopia, ethnoveterinary medicinal plants and associated indigenous practices are not adequately documented. This study aimed to identify and document ethnoveterinary medicinal plants with their associated indigenous practices along with the habitats of these plants in Ensaro district.

Methods: This ethnobotanical survey included 389 informants (283 males and 106 females) from all 14 kebeles of Ensaro district, which is the smallest administrative unit in Amhara Regional State's North Shewa Zone. Systematic random and intentional sampling techniques have been used to obtain representative informants. Ethnobotanical data were collected during the 13th of February 2019 and the 26th of October 2020 through Semi-structured interviews, field observation, a guided field walk, and focus group discussions.

Results: We identified and recorded 44 medicinal plants belonging to 43 genera and 28 families that are used in Ensaro district to manage livestock diseases. The analysis of collected information from informants showed that shrubs constituted the highest number of species, leaves were the most highly harvested parts for the preparation of remedies and oral administration was the main route to apply medicines to treat internal diseases of livestock.

Conclusion: In general, the findings of this study revealed diverse ethnoveterinary medicinal plants and associated indigenous practices about their use in the Ensaro District. The majority of farmers trust traditional ethnoveterinary medicines due to their higher efficacy, lower price, and easy availability. Data from this study can be used to preserve important medicinal plants for sustainable utilization and drug formulation.

\section{Introduction}

Limited distribution of modern veterinary health care services along with the unaffordable cost of modern drugs which sometimes fail to exert desired benefits, many farmers in developing countries depend on traditional medicines for the management of diseases of livestock for many centuries (Abera \& Mulate, 2019). Ethnoveterinary medicine refers to the peoples' beliefs, knowledge, skills, methods, and practices related to animal health that are used extensively in rural regions as a primary source of medicine to treat livestock diseases (McCorkle \& Green, 1998; WHO, 2002).

Ethiopia has one of the largest livestock populations in Africa which is a major contributor to the overall economy of the country (Shapiro et al., 2017). thus, livestock production is a crucial element of agriculture in the country (Asresie et al., 2015). Despite its significant economic benefits, livestock productivity is low (Yami et al., 2013). The low output has been attributed in part to the poor health of its animals (Tonamo, 2016; Tufa et al., 2018). Due to the enormous potential of medicinal plants in Ethiopia, traditional herbal medicine is an integral part of local culture and is widely used to treat human and livestock diseases (Giday \& Teklehaymanot, 2013; Eshetu et al., 2015).

Although plant-based traditional medicines met the primary healthcare needs, ethnoveterinary practice is harmed by acculturation and depletion of plant habitats because of environmental degradation, deforestation, and overexploitation of medicinal plants themselves (Feyera et al., 2017; Mahmoud et al., 2020). Furthermore, ethnoveterinary knowledge and practices have been passed down through the generations by oral stories instead of in recorded form (Yirga et al., 2012). On the other side, ethnoveterinary traditions are eroding without adequate

Page $2 / 24$ 
documentation and analysis of effective medicinal plants and the associated indigenous knowledge (Abera \& Mulate, 2019). Yet, there has been very little effort to assess and document ethnoveterinary medicinal plants in the Amhara Region and Ethiopia. As far as our literature search, there are no ethnoveterinary medicinal plant studies in Ensaro district. Thus, the present study was designed to assess and document the ethnoveterinary medicinal plants and associated indigenous practices in Ensaro District, Amhara Region, Ethiopia.

\section{Methods}

\subsection{Description of the study area}

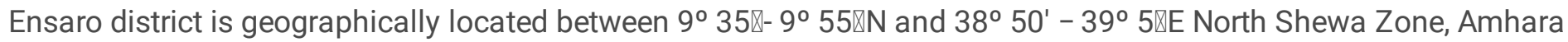
Regional State, Ethiopia. The total area of the district is about 44,217.6 ha (Fig. 1). Most of the district is lowland (Fig. 1) with a mean annual rainfall of $1174 \mathrm{~mm}$ and a temperature of $17.7^{\circ} \mathrm{C}$. The total population is about 74312 (CSA, 2013), out of which $94.7 \%$ inhabit rural areas, deriving their livelihood from mixed agriculture (Cherinet \& Mekonnen, 2019).

Ensaro district was selected purposively for this study. This district is one of the drought-affected districts in the North Shewa Zone of Amhara Regional State. As reported by Cherinet and Mekonnen (2019), in the district there is a trend of increasing mean annual temperature and decreasing mean annual rainfall for the three decades. This harms the vegetation of the area and initiates this research to check the status of cultural knowledge regarding medicinal plants and the plant taxa in the district. There are 14867 households in the district and the major economic activity of the population is a mixed farming system. Based on the information gathered during the reconnaissance survey, the district has fourteen smaller administrative units at different distances from the administrative center (Lemi Town). All these units were included in this ethnobotanical investigation.

\section{Study sites and informant selection techniques}

The study district and informants were selected based on the information collected from Ensaro district administration office, health centers administrators, agricultural office, and other people in the study area during reconnaissance survey prior to actual data collection. As the result, since the district the smallest district and contains only 13 kebeles with 14560 households, all kebeles namely Lemi, Diremu, Denbina girarge, Wokelona antsokiya, Salayishna dereku, Gezawashana dalota, Lamgeno, Yidno, Kenina moltaba, Karambana tikur dur, Beressa, Goshuhana qeq, and Woko fikreselam were taken for data collection. Both systematic random and intentional sampling techniques have been used to obtain representative informants following previous publications (Yineger \& Yewhalaw, 2007; Lulekal et al., 2013).

To decide sample size, a quantitative model suggested by Cochran (2007) was adopted as shown below: $\mathrm{n}=\frac{N}{1+N(\boldsymbol{e})} 2$,

Where $\mathrm{n}$ is the sample size, $\mathrm{N}$ is a total number of households in the selected kebeles [the sample size ( $\mathrm{n}$ ) in each Kebele was picked based on its proportion to $\mathrm{N}$ because the number of households in each Kebele is different], $\mathrm{e}$ maximum variability or margin of error $10 \%(0.1), 1$ = probability of the event occurring. Based on the above technique, 14560

$\mathrm{n}=\overline{1+14560(0.05)^{2}}=389$ sample households were selected.

Two hundred eighty (294) general informants were systematically selected from total households. The list of households was obtained from Woreda agricultural office in the study area. Fourteen thousand five hundred sixty households (14560) was divided by sample size (389) whose age ranges from 20 to 90 years and it gave 37 . So that 
the nth value is 37 . One number was obtained randomly between 1 and 37 . The number was five. So that every 37 th number was selected to get sampled household. It also assures that the community will be evenly sampled. Hence, additional information on medicinal plant species and associated indigenous knowledge were gathered from general informants with random sampling techniques. General informants were ordinary people who were found in the study area for a long period of time and used their indigenous medicinal plant knowledge within their families. Hence, general informants were included as respondents to gather additional data and check the transfer of indigenous knowledge within the people.

The ninety-five key informants (77 men and 18 women) who were traditional healers purposely selected based on the recommendations of elders, local authorities, and religious leaders. Information regarding healers was obtained from each sampled kebele health offices and other people. On the other hand, the snowball sampling technique was used to get hold of healers who had no official permission for their traditional medicinal practices and who were found through the suggestion of other interviewed informants confidentially. As the names of non-legalized healers were not registered in the governmental offices and the people hesitated to report their names freely, the use of a snowball sampling technique was useful.

To contact informants, various procedures had to be followed.to begin, legal supportive letter were obtained from Ethiopian public health institute. The objective of the research was described to the administrators of the district, agricultural and health officials in Ensaro district. Accordingly, they allowed and gave a cooperative letter to conduct the study in the district. Finally, they sent letters of research permission to all kebeles' chairpersons and health office officials. Therefore, list of officially recognized traditional healers were obtained together with the type of diseases they treat. in addition to that the kebele chairpersons and health officers conveyed messages for the people concerning their participation in the study. People were informed about the objective of the study by kebele chairpersons and health officers and researchers. Interview was conducted with only willing informants to participate in the study.

\section{Methods of data collection and procedures}

Ethnobotanical data were collected during the 13th of February 2019 and the 26th of October 2020 through Semistructured interviews, field observation, a guided field walk, and focus group discussions (Martin, 1995; Cotton \& Wilkie, 1996). The semi-structured interviews were prepared ahead of time in the English language and translated during the interview that is the mother tongue of informants. Informant interview was conducted individually (Martin, 1995; Alexiades \& Sheldon, 1996) to obtain information about medicinal plant species, parts used, preparation techniques, and common human diseases treated, administration routes and dosage. Ethnobotanical data regarding habitat, abundance and the threat of medicinal plants were also collected. The voucher specimen of all mentioned medicinal plants during the interview were collected from different habitats with the assistance of traditional healers. Essential information such as GPS data, the local name of the plant, habitat, and life forms of plant specimens were recorded. Specimens were numbered, pressed, dried, identified, and deposited at the national herbarium of Ethiopia in Addis Ababa University, Ethiopia. Plant identification was performed using the flora of Ethiopia and Eritrea. The accuracy of identification was confirmed by the comparison with the deposited authenticated specimens from Addis Ababa University Herbarium and by the help of supervisors.

\subsection{Data analysis}

To summarize demographic features of participants and medicinal plant data, descriptive statistics such as percentiles and frequencies were utilized. A summary table was created to report the raw data of medicinal taxa, including their scientific names, family names, main indications, animal species treated, method of preparation, 
number of citations, and other important parameters required in reporting ethnopharmacological field studies based on (Heinrich et al., 2018; Weckerle et al., 2018).

Data were entered into an MS Excel spreadsheet for statistical analysis. Both qualitative and quantitative using preference ranking, direct matrix ranking, and fidelity level (species consensus) were analyzed. The results were presented using tables, graphs, and percentages following (Martin, 1995).

Fidelity level values were to determine the relative healing potential of each medicinal plant based on the proportion of informants who agreed on its use against a given disease category (Tardío \& Pardo-de-Santayana, 2008). Fidelity level was estimated using a formula:

$\mathrm{FL}(\%)=\frac{I_{P}}{I_{U}} \times 100$

Where $\mathrm{FL}(\%)$ is fidelity level, IP is the number of respondents who reported the utilization of medicinal plants for a specific main ailment and IU is the total number of respondents who mentioned the same plant for any ailment (Friedman et al., 1986). This technique helps to recommend those medicinal plants having high fidelity levels are more effective that can be further analyzed for their antimicrobial activity and drug formulation (Heinrich, 2000).

The informant consensus factor (ICF) was computed to see the agreement of informants for a plant species in treating a disease using the following formula:

$\mathrm{ICF}=\frac{n_{u r-n_{t}}}{n_{u r}-1}$

Where ICF is informant consensus factor, $n_{u r}$ is the number of use citations and $n_{t}$ is the number of plant species used following (Vitalini et al., 2013).

Direct matrix ranking exercise was used to compare the use diversity of a given plant species using the methods proposed by Martin (1995); Cotton and Wilkie (1996). The multipurpose uses of medicinal plant species were selected out of the total medicinal plants. Key informants listed the uses of these species. These key informants were asked to assign use values to each species as follows ( $5=$ best, $4=$ very good, $3=$ good, $2=$ less used, $1=$ least used and $0=$ not used). The average values (scores) given to each medicinal plant species were summed up and ranked. Moreover, the ten key informants were also involved in a priority ranking exercise that was focusing on perceived threatening factors of the medicinal plant species.

In the end, preference ranking from informants' responses on ideas related to disease treatment was analyzed following (Martin, 1995). Based on their preferences ranking, they ranked individually those selected medicinal plants in treating the mentioned ailments following previous scholars (Cotton \& Wilkie, 1996).

\section{Ethical consideration}

The study was carried out after being approved by the Ethiopian public health institute, traditional medicine directorate. Before filling the questionnaires, the participants' consent was obtained and they were assured that their responses would be used only for research purposes, and the information given would be treated with utmost care and confidentiality.

\section{Results}




\subsection{Demographic profiles of respondents}

In this study, 389 informants (95 key informants and 294 general informants) were involved. Most of the participants were men $(72.8 \%)$ and the rest $27.2 \%$ were women. The age of participants ranges from 20 to 90 with a mean value of 48.5 years. Regarding educational status $48 \%$ of the informants were literate and the rest $52 \%$ were illiterate(Table 1).

Table 1

Demographic details of the informants

\begin{tabular}{|c|c|c|c|c|c|c|}
\hline \multirow[t]{2}{*}{ Gender } & \multicolumn{3}{|c|}{ Age groups in years } & \multicolumn{3}{|c|}{ Educational status } \\
\hline & $\begin{array}{l}20-35 \\
\text { (young) }\end{array}$ & $\begin{array}{l}36-60 \\
\text { (adult) }\end{array}$ & $\begin{array}{l}\text { Above } 60 \\
\text { (elderly) }\end{array}$ & $\begin{array}{l}\text { Modern } \\
\text { education }\end{array}$ & $\begin{array}{l}\text { Religions } \\
\text { education }\end{array}$ & Illiterate \\
\hline Men & 57 & 161 & 65 & 100 & 34 & 149 \\
\hline Women & 54 & 46 & 6 & 53 & 0 & 53 \\
\hline Total & $111(28.5 \%)$ & $207(53.2 \%)$ & $71(18.3 \%)$ & $153(39.33 \%)$ & $34(8.74 \%)$ & $202(51.93)$ \\
\hline
\end{tabular}

\subsection{Traditional knowledge of the community}

When mean number of medicinal plants compared between men and women using independent t-test, there was significant difference $(p<0.05)$. More number of medicinal plants were listed by men than women. Similarly, there was statistically significant difference $(p<0.05)$ between key and general informants; rural and urban participants $(p<$ 0.05) (Table 2).

Table 2

Statistical test of significance and independent $t$ test on the number of medicinal plants mentioned by informant groups in Ensaro District

\begin{tabular}{|c|c|c|c|c|c|}
\hline Parameters & Informant groups & $\mathbf{N}$ & mean & T-value & P-value \\
\hline \multirow[t]{2}{*}{ Informant types } & General informants & 294 & 4.1 & \multirow[t]{2}{*}{2.126} & \multirow[t]{2}{*}{$0.035^{\star}$} \\
\hline & Key informants(healers) & 95 & 4.6 & & \\
\hline \multirow[t]{2}{*}{ Gender } & Men & 283 & 4.7 & \multirow[t]{2}{*}{9.134} & \multirow[t]{2}{*}{$0.0001^{\star}$} \\
\hline & Women & 106 & 3.1 & & \\
\hline \multirow[t]{2}{*}{ Place of residence } & Rural & 368 & 3.8 & \multirow[t]{2}{*}{15.76} & \multirow[t]{2}{*}{$0.0001 *$} \\
\hline & Urban & 21 & 1.2 & & \\
\hline
\end{tabular}

*Significant difference $(\mathrm{P}<0.05)$, **t $(0.05)$ (two tailed), $\mathrm{df}=388, \mathrm{~N}=$ number of respondents 
Table 3

Statistical test of significance using one-way anova test on the number of medicinal plants mentioned by informants' age groups in Ensaro District

\begin{tabular}{|c|c|c|c|c|}
\hline Age groups & Total number of medicinal plants mentioned & Mean \pm SD & F-test & P-value \\
\hline Young ( $19-35$ years) & 284 & $2.56 \pm 0.85^{\mathrm{a}}$ & 159.2 & $0.0001^{*}$ \\
\hline Adult (36-60 years) & 927 & $4.48 \pm 2.08^{b}$ & & \\
\hline Elderly (above 60 years) & 438 & $6.17 \pm 2.77^{c}$ & & \\
\hline
\end{tabular}

*Significant difference $(P<0.05)$, **t $(0.05)$ (two tailed), df $=388, N=$ number of respondents

\subsection{Medicinal plants of the study area}

This study documented 44 ethnoveterinary medicinal plants distributed in 43 genera and 28 families, which are used to treat 16 livetock ailments (appendix: Table 11). Seven medicinal plant families were represented by two or more species while twenty-two families were represented by a single species each (Table 4). Solanceae was the dominant family contributing four species (9\%), followed by Amaranthaceae,Asteraceae, Euphorbiaceae, Fabaceae and Lamiaceae each with three species $(7 \%)$. This implies that about $57 \%$ of families were represented by more than one species.

Table 4

Diversity of medicinal plants in each plant family

\begin{tabular}{|llll|}
\hline No & Plant families & Number of species & Percentage \\
\hline 1 & Solanaceae & 4 & $9 \%$ \\
\hline 2 & Amaranthaceae & 3 & $7 \%$ \\
\hline 3 & Asteraceae & 3 & $7 \%$ \\
\hline 4 & Euphorbiaceae & 3 & $7 \%$ \\
\hline 5 & Fabaceae & 3 & $7 \%$ \\
\hline 6 & Lamiaceae & 3 & $7 \%$ \\
\hline 7 & Poaceae & 2 & $5 \%$ \\
\hline 8 & Rutaceae & 2 & $43 \%$ \\
\hline 9 & The rest & 19 & \\
\hline Total & & 41 & $5 \%$ \\
\hline
\end{tabular}

\subsection{Growth forms of medicinal plants}

The analysis of the growth habits of medicinal plants indicated that shrubs constitute the highest number of species $(23,53.7 \%)$ followed by herbs $(14,34.2 \%)$, trees $(5,11.4 \%)$, and climbers $(1,2.4 \%)$. About $90 \%$ of medicinal plants were collected from wild habitats and very few (10\%) were cultivated in the home garden (Fig. 2).

\subsection{Parts used}

The study revealed that diverse types of plant parts were used to treat various ailments of livestock either in combination or alone. The analysis of collected information showed that leaves were the widely used plant parts that 
accounted for $51 \%$ followed by root $25 \%$, fruit $12 \%$, and the rest all accounted for $12 \%$ (Fig. 3)

\subsection{Conditions of preparation}

Medicines were prepared in fresh, dry, or both dry and fresh conditions of plant parts. The Marjory of traditional herbal medicines prepared in fresh form (79\%), followed by fresh/dry (13\%) form and in dry form (8\%) Fig. 4.

\subsection{Preparation methods}

Table 5. illustrates the different types of traditional remedy preparations from medicinal plant parts. The main preparation method was crushing of the fresh or dried plant materials that accounted for (60\%), followed by unprocessed plant (10\%) and powdering and baking (6\%).

Table 5

Modes of preparation of medicinal plants in Ensaro District. Types and percentages of preparation forms of traditional plant medicines

\begin{tabular}{|cll|}
\hline No & Preparation methods & Percent \\
\hline 1. & Crushing & $60 \%$ \\
\hline 2. & Unprocessed & $10 \%$ \\
\hline 3. & Powdering and baking & $6 \%$ \\
\hline 4. & Crushing and squeezing & $4 \%$ \\
\hline 5. & Powdering & $4 \%$ \\
\hline 6. & Squeezing/Powdering & $4 \%$ \\
\hline 7. & Squeezing & $4 \%$ \\
\hline 8. & Powdering and smoking & $2 \%$ \\
\hline 9. & Crushing and boiling & $2 \%$ \\
\hline 10. & Cutting & $2 \%$ \\
\hline
\end{tabular}

\subsection{Methods of application}

This study reported a wide range of traditional remedy applications. Adding through the mouth was the most common, accounting for $50 \%$, followed by dropping and smearing (15\% of each) (Fig. 5).

\subsection{Ingredients added during remedy preparation}

Solvents and ingredients are required for the preparation of traditional medicines. Water was the most common solvent, accounting for 63 percent of the total, but $29 \%$ of remedies preparations did not need additives (Fig. 6).

\subsection{Routes of applications}

The current study indicated the different routes for the applications of traditional herbal medicines for the treatment of various types of livestock ailments and diseases. Oral administration is the most used route (58.3\%) which followed by the dermal application (20.8\%) while the optical and nasal routes contributed (20.9\%) (Fig. 7). 
In this study district, 44 medicinal plants were collected and identified for the treatment of 17 types of livestock health disorders. Most health disorders of livestock in the study area are treated by more than one species (Table 6). For instance, Blackleg is treated by Cucumis ficifolius, Eucalyptus globulus, Foeniculum vulgare, and Nicotiana tabacum. Several diseases can also be treated by a single medicinal plant species. For example, anthrax and blackleg treated by Cucumis ficifolius (Table 6)

Table 6

Livestock diseases treated by medicinal plants in the study area

\begin{tabular}{|c|c|c|c|}
\hline No & Ailments & Frequency & Number of medicinal plants used \\
\hline 1. & Blackleg & 84 & 13 \\
\hline 2. & Eye disease & 70 & 9 \\
\hline 3. & Footrot & 44 & 4 \\
\hline 4. & Leech & 30 & 5 \\
\hline 5. & Jaundice & 21 & 3 \\
\hline 6. & Rabies & 18 & 3 \\
\hline 7. & Tail Amputation & 18 & 3 \\
\hline 8. & Tumor & 15 & 3 \\
\hline 9. & Anthrax & 16 & 4 \\
\hline 10. & 'mitch' (febrile illness) & 13 & 1 \\
\hline 11. & Diarrhoea & 12 & 1 \\
\hline 12. & External parasites (ticks) & 11 & 1 \\
\hline 13. & Lung disease & 10 & 1 \\
\hline 14. & Rh-factor & 6 & 2 \\
\hline 15. & Swelling & 4 & 1 \\
\hline \multirow[t]{2}{*}{16.} & Wound & 3 & 1 \\
\hline & Total & 375 & \\
\hline
\end{tabular}

\subsection{Preference ranking}

The five most reported medicinal plants for effective treatment of blackleg that were frequently reported in the study area were selected for preference ranking exercise. Ten key informants were asked to rank the given medicinal plants based on their usefulness. They were also asked to give numbers 5 for effective and 1 for the less effective medicinal plants. As the result, Cucumis ficifolius was ranked first and Allium sativum ranked second whereas Verbascum sinaticum was ranked last (Table 7). 
Table 7

Simple preference ranking values of five medicinal plants used to treat blackleg

\begin{tabular}{|c|c|c|c|c|c|c|c|c|c|c|c|c|}
\hline \multirow[t]{2}{*}{ Name of medicinal plants } & \multicolumn{10}{|c|}{ Informants from (A-J) } & \multirow[t]{2}{*}{ Total } & \multirow[t]{2}{*}{ Rank } \\
\hline & A & B & C & D & E & $\mathbf{F}$ & G & $\mathrm{H}$ & I & $J$ & & \\
\hline Cucumis ficifolius & 4 & 5 & 4 & 5 & 5 & 4 & 4 & 5 & 5 & 5 & 46 & $1 \mathrm{st}$ \\
\hline Salvia nilotica & 3 & 5 & 3 & 4 & 2 & 1 & 3 & 2 & 1 & 2 & 26 & 4th \\
\hline Allium sativum & 5 & 3 & 2 & 4 & 3 & 3 & 4 & 5 & 2 & 3 & 34 & $3 r d$ \\
\hline Verbascum sinaticum & 5 & 3 & 4 & 4 & 3 & 2 & 1 & 4 & 5 & 4 & 35 & 2nd \\
\hline Ruta chalpensis & 2 & 4 & 2 & 3 & 2 & 1 & 2 & 3 & 3 & 3 & 25 & 5th \\
\hline
\end{tabular}

\subsection{The relative healing potential of medicinal plants used to treat livestock diseases}

To identify the most preferred medicinal plant species used to treat livestock ailments in the study area. Hence, Ocimum lamiifolium, Albizia anthelmintica, Phytolacca dodecandra, Dichrostachys cinerea, Andrachne aspera Spreng, Psydrax schimperiana, Emilia sonchifolia, Clematis simensis, Calpurnia aurea, Silene macrosolen, and Securidaca longipedunculata Fresen had the highest fidelity level values that used as a sign of their healing potential in the study area (Table 8). 
Table 8

FL values of the 15 most referenced medicinal plants

\begin{tabular}{|lllll|}
\hline Medicinal plant species & Diseases & Ip & lu & Fidelity level value (\%) \\
\hline Salvia & Blackleg & 31 & 62 & 50 \\
\hline Inula confertiflora & Eye disease & 68 & 70 & 97.1 \\
\hline Clerodendrum myricoides & Anthrax & 41 & 69 & 59.4 \\
\hline Nicotiana tabacum & Leech & 38 & 40 & 95 \\
\hline Verbascum sinaticum & Tumour & 29 & 31 & 93.5 \\
\hline Justiciar schimperiana & Jaundice & 19 & 27 & 70.4 \\
\hline Cucumis ficifolius A. Rich. & Foot rot & 28 & 34 & 82.4 \\
\hline Cucumis ficifolius A. Rich. & Tail Amputation & 16 & 29 & 55.2 \\
\hline Phytolacca dodecandra & Rabies & 29 & 36 & 80.6 \\
\hline Solanecio gigas & "Chirt" (trypanosomiasis) & 10 & 16 & 62.5 \\
\hline Cynodon dactylon & Rh-factor & 8 & 8 & 100 \\
\hline Achyranthes aspera & Wound /bleeding & 12 & 15 & 80 \\
\hline Carissa spinarum & Lung disease & 6 & 11 & 54.5 \\
\hline Calpurnia aurea & External parasites(ticks) & 28 & 37 & 75.7 \\
\hline Clutia abyssinica & Diarrhea & 18 & 23 & 78.3 \\
\hline
\end{tabular}

\subsection{Informant consensus factor}

To compute informant consensus factor values (ICF values), diseases of the study area were grouped into eight ailment categories. As the result, digestive system scored the highest ICF value (0.86), followed by dermal and parasitic caused diseases (0.84) and (0.83), respectivly(Table 9). Among the digestive system diseases, blackleg was the top recorded livestock health disorder in Ensaro District veterinary office. Blackleg was traditionally treated with 13 medicinal plant species such as Salvia nilotica, Cucumis ficifolius, Allium sativum, Verbascum sinaticum, Ruta chalpensis, Justicia schimperiana and so son (appendix:Table 11). 
Table 9

ICF values of traditional medicinal plants for treating livestock ailments in Ensaro district

\begin{tabular}{|lllll|}
\hline Diseases categories & ailments & $\mathbf{N}_{\text {ur }}$ & $\mathbf{N}_{\mathbf{t}}$ & ICF values \\
\hline Digestive system & Blackleg, Anthrax and Diarrhoea & 124 & 18 & 0.86 \\
\hline Dermal & Wound, swelling, Tumour, Tail Amputation and footrot & 74 & 12 & 0.84 \\
\hline Parasitic causes & Leech and ticks & 31 & 6 & 0.83 \\
\hline Respiratory diseases & Lung disease and "mitch" (fibril ilness) & 5 & 2 & 0.75 \\
\hline Viral causes & Rabies and Jaundice & 20 & 6 & 0.74 \\
\hline Reproductive disease & Rh-factor & 4 & 2 & 0.67 \\
\hline Sense organ diseases & Eye disease & 18 & 9 & 0.53 \\
\hline
\end{tabular}

\subsection{Direct matrix ranking exercise}

In addition to food values, the local people used the plants for other different purposes such as fuelwood, fence, food, medicine, charcoal, and furniture. The result of direct matrix ranking revealed that Juniperus procera, Acacia etbaica, Croton macrostachyus, Silene macrosolen, Buddleja polystachya, Eucalyptus globulus, Millettia ferruginea, Carissa spinarum, Citrus aurantiifolia was ranked first to ninth, respectively. Similarly, the seven use-values reported on six selected plant species were summed up and ranked and, the result showed that fuelwood collection, fence, farm implements, house construction, medicine, food were ranked first, second, third, fourth, fifth, sixth, and seventh, respectively (Table 10).

Table 10. Direct matrix ranking of six plant species by twelve informants based on seven use criteria ( $5=$ best; $4=$ very good; 3 =good; 2 = less used; 1 =least used and $0=$ no value) 


\begin{tabular}{|c|c|c|c|c|c|c|c|c|c|}
\hline \multirow[t]{2}{*}{ Species } & \multicolumn{9}{|c|}{ Use diversity } \\
\hline & Medicine & $\begin{array}{l}\text { Agricultural } \\
\text { expansion }\end{array}$ & Fence & $\begin{array}{l}\text { Fuelwood } \\
\text { collection }\end{array}$ & furniture & Charcoal & Food & total & Rank \\
\hline $\begin{array}{l}\text { Citrus } \\
\text { aurantiifolia } \\
\text { (Christm.) } \\
\text { Swingle }\end{array}$ & 3 & 2 & 4 & 1 & 1 & 1 & 0 & 12 & $7^{\text {th }}$ \\
\hline $\begin{array}{l}\text { Buddleja } \\
\text { polystachya } \\
\text { Fresen. }\end{array}$ & 3 & 3 & 1 & 5 & 5 & 1 & 0 & 18 & $5^{\text {th }}$ \\
\hline $\begin{array}{l}\text { Carissa } \\
\text { spinarum }\end{array}$ & 2 & 3 & 2 & 0 & 0 & 4 & 3 & 14 & $6^{\text {th }}$ \\
\hline $\begin{array}{l}\text { Millettia } \\
\text { ferruginea }\end{array}$ & 3 & 4 & 5 & 4 & 1 & 3 & 4 & 24 & $2^{\text {nd }}$ \\
\hline $\begin{array}{l}\text { Eucalyptus } \\
\text { globulus }\end{array}$ & 1 & 4 & 1 & 2 & 3 & 0 & 0 & 11 & $8^{\text {th }}$ \\
\hline $\begin{array}{l}\text { Juniperus } \\
\text { procera }\end{array}$ & 3 & 4 & 4 & 5 & 5 & 3 & 3 & 27 & $1^{\text {st }}$ \\
\hline $\begin{array}{l}\text { Croton } \\
\text { macrostachyus } \\
\text { Hochst. ex Del. }\end{array}$ & 4 & 5 & 3 & 5 & 5 & 0 & 0 & 22 & $3^{\text {rd }}$ \\
\hline Acacia etbaica & 1 & 5 & 3 & 5 & 5 & 0 & 0 & 19 & $4^{\text {th }}$ \\
\hline Total & 20 & 30 & 23 & 27 & 25 & 12 & 10 & & \\
\hline Rank & $5^{\text {th }}$ & $1^{\text {st }}$ & $4^{\text {nd }}$ & $2 \mathrm{rd}$ & $3^{\text {th }}$ & $6^{\text {th }}$ & $7^{\text {th }}$ & & \\
\hline
\end{tabular}

\section{Discussion}

In this study, we have investigated ethnoveterinary medicinal plants, parts used, preparation methods, and livestock diseases treated in Ensaro district, North Shewa Zone, Amhara Regional State, Ethiopia. For the study, 389 informants (95 key informants and 294 general informants) were involved with an age range from 20-90 years. Many key informants were unwilling to disclose their knowledge particularly to show and the type of medicinal plants and to tell their names because they thought that the plant will lose its efficacy while they disclose them. But at the verge of their age, they will transfer this knowledge orally to one of their sons to whom is considered as loyal to keep the knowledge not leaked out their bloodline.

The distribution of ethnoveterinary knowledge between genders revealed that the majority of informants were men (72.3\%). This is since, in most of Ethiopia, the major responsibilities of women are restricted in the home and homestead while most of the outdoor activities are performed by men which exposes them to share knowledge with others. Another possible reason might be indigenous knowledge is passed on to the son mainly to the first son. This aligns with the research result of Yigezu et al. (2014) that more than ninety percent of ethnoveterinary practitioners were male and the study carried out by Birhan et al. (2018) in Enarj Enawga District, East Gojjam Zone, Amhara Region, Ethiopia also indicated consistent finding. This indicated that indigenous knowledge is not equally distributed between gender in the country. 
Concerning educational status, $48 \%$ of them were literate while $52 \%$ were illiterate. However, illiterates have been mentioned more number medicinal plants with their medicinal values than literates. This implies that education particularly modern education has negatively impacting indigenous knowledge.

The present study identified and documented 44 ethnoveterinary medicinal plants, which are used to treat 16 types of livestock health disorders in Ensaro district, North Shewa Zone, Ethiopia. This indicated that the current study area has a good status of ethnoveterinary medicinal plants and associated indigenous knowledge regardless of its vegetation cover. This may be because, in developing countries, medicinal plants have remained the most economically affordable and easily accessible source of treatment for a variety of livestock health problems (Khan et al., 2019; Adeniran et al., 2020; Dzoyem et al., 2020; Gonfa et al., 2020).

The number of medicinal plants documented in this study was comparable with similar previous studies in different parts of Ethiopia and other countries. In a study conducted in Ada'ar District, Afar Regional State, Ethiopia, 49 ethnoveterinary medicinal plants were identified, documented, and published by Giday and Teklehaymanot (2013). Similarly, another report by Tamiru et al. (2013) of the study in Dabo Hana District, West Ethiopia also showed that they identified and recorded 48 ethnoveterinary medicinal plants for treating 22 types of livestock diseases. In Ankober District, North Shewa Zone, Amhara Regional State, 51 medicinal plants distributed in 50 genera and 35 families were reported by Lulekal et al. (2014). An ethnoveterinary study conducted by Njoroge and Bussmann (2006) in Kenya showed that the Kikuyus people are using 40 medicinal plants to treat different kinds of cattle diseases. This finding demonstrated that ethnoveterinary medicines are still important in the prevention and control of livestock diseases in Ethiopia and other parts of developing countries.

Most of the ethnoveterinary medicinal plants identified and documented in this study were also be reported in previous studies conducted out in different parts of Ethiopia. Among 42 medicinal plant species documented in this study, 7 species in Enarj Enawga District, East Gojjam Zone, Amhara Region, Ethiopia by Birhan et al. (2017), 20 species at Bale Mountains National Park, Ethiopia by Yineger et al. (2007), 9 species in different selected districts of Southern Ethiopia by Eshetu et al. (2015), 9 species in Seharti-Samre district, Northern Ethiopia by Yirga et al. (2012), 16 species Ankober District, North Shewa Zone, Amhara Region, Ethiopia by Lulekal et al. (2014), 15 species in Abergelle, Sekota and Lalibela districts of Amhara region, Northern Ethiopia by Assefa and Bahiru (2018), 8 species in Leka Dullecha District, Western Ethiopia by Tesfaye and Erena (2020), 8 species in South Wollo Zone, Amhara region, Ethiopia by Wodegebriel et al. (2018) were documented. These findings revealed that there is widespread use of ethnoveterinary medicinal plants and associated indigenous knowledge in controlling and prevention of livestock diseases in Ethiopia.

The analysis of our data also showed that Solanaceae, Asteraceae, Euphorbiaceae, and Lamiaceae accounted for the largest share of the reported ethnoveterinary medicinal plant families. Solanaceae with 4 species, Asteraceae, Euphorbiaceae, and Lamiaceae with three species each. Similar investigations conducted in Ethiopia (Lulekal et al., 2014; Tekle, 2015; Birhan et al., 2017) and elsewhere (Njoroge \& Bussmann, 2006) documented the dominance of these families in the traditional medicines used to treat livestock diseases. This indicated the wider distribution and abundance of these plant families in east Africa. Furthermore, the widespread use of species from these families could be linked to their more effective treatments against diseases (Gazzaneo et al., 2005).

Many of the documented plants in Ensaro district were shrubs (53.7\%) that could be linked to an abundance of shrubby plant species in the study area. Similar ethnobotanical studies reported the most abundant use of shrubs in ethnoveterinary medicines (Giday \& Teklehaymanot, 2013; Lulekal et al., 2014; Alebie \& Mehamed, 2016). Other researchers (Yineger et al., 2008; Eshetu et al., 2015; Birhan et al., 2017; Wodegebriel et al., 2018) found that herbaceous species dominated ethnoveterinary medicine preparations in different regions of Ethiopia. This difference

Page $14 / 24$ 
in the use of different life forms of ethnoveterinary plants revealed the existence of different agroecology and indigenous knowledge in various parts of Ethiopia.

Similar to other ethnobotanical inventories conducted in different regions of the country (Lulekal et al., 2014; Birhan et al., 2017), the majority of ethnoveterinary medicinal plants (87.8\%) in the present study were collected from wild habitats. In Ethiopia, it is popular to use wild or uncultivated medicinal plants to treat livestock and human diseases (Giday \& Teklehaymanot, 2013; Megersa et al., 2013). This implies that the domestication of medicinal plants is not yet the tradition of the users in the country. This may lead to overexploitation and threatening of these plants as there are no conservation actions.

According to our findings, leaves (51\%) were the most commonly used plant parts in the study district for the preparation of remedies for the treatment of livestock diseases. In line with the current study, other studies in Ethiopia found that leaves were the most frequently used plant part to treat livestock diseases (Lulekal et al., 2014; Feyera et al., 2017; Kebede et al., 2017).

To make effective and efficient treatments, the majority of ethnoveterinary practitioners in the study district used fresh plant materials (79\%). The use of fresh plant materials for remedy preparations is well documented elsewhere in Ethiopia (Lulekal et al., 2014; Eshetu et al., 2015; Maryo et al., 2015; Wodegebriel et al., 2018) as fresh plant materials maintain the majority of bioactive compounds when compared to dry plant materials as they lose volatile but important secondary metabolites.

The majority of informants confirmed that the bulk of preparations (60\%) were made by crushing and mixing with water, which is consistent with prior findings from other studies (Eshetu et al., 2015; Kidane et al., 2018). Most informants reported that the main means of administering medicine was oral treatment which agrees with the findings of (Giday et al., 2009; Maryo et al., 2015).

The calculation of fidelity level of medicinal plants found out that Cynodon dactylon, Inula confertiflora, Nicotiana tabacum, Verbascum sinaticum, and Cucumis ficifolius had high fidelity levels. according to Trotter and Logan (1986), fidelity level is a measure of the healing ability of medicinal plants. Therefore, medicinal plants having a high-fidelity level indicates that they are speculated to be effective in their curing potential and can be a good candidate for modern drug formulation.

In addition, the calculation of informant consensus factor values showed that prevalent diseases in the study area have higher informant consensus factor values and less prevalent diseases showed smaller informant consensus values. In addition, the lower values of informant consensus factors indicated that the willingness of sharing indigenous knowledge among traditional healers is minimum. Probably this is due to the belief that their healing activity cannot work if the secret is revealed to others in the study district. Furthermore, traditional healers living in different habitats may use different medicinal plant species to treat the same diseases. The informant consensus values also suggested that people in the community share knowledge about the most significant medicinal plant species for treating the most common ailments.

The preference ranking exercise helped in determining which medicinal plant species are most used to treat blackleg that is frequently reported in the study area. As the result, salvia nilotica, Allium sativum, Cucumis ficifolius, Verbascum sinaticum, and Ruta chalpensis had the highest scores and were identified as the most effective treatments for this disease. Future research on the bioactive components of these medicinal plant species against blackleg also may lead to a good result for the development of drugs. 
The results of a direct matrix ranking exercise revealed that the highest values (ranks) for several multipurpose ethnoveterinary medicinal plants in the study area such as Juniperus procera, Millettia ferruginea, Croton macrostachyus, Acacia etbaica, Buddleja polystachya, and Carissa spinarum. This result suggested that these plants are overexploited for non-medicinal purposes rather than for their reported medicinal values. Overharvesting of multipurpose medicinal plants for agricultural land expansion, fuelwood collection, cutting for furniture production, fence, house construction, and charcoal production, and other purposes was identified as contributing factors to the depletion of such species in the study area. As the result, the findings require immediate conservation actions to protect the rapidly declining multipurpose ethnoveterinary medicinal plant species of the study area. The same results showing the highest exploitation of multipurpose ethnoveterinary medicinal plants have been documented from different regions of Ethiopia (Yineger et al., 2007).

\section{Conclusion}

This research was aimed to document ethnoveterinary medicinal plants and associated indigenous knowledge in Ensaro district. From quantitative and qualitative analysis, it can be concluded that the study area is rich in the diversity of medicinal plants which used to treat livestock diseases. Yet, indigenous knowledge of using medicinal plants to tackle livestock health disorders is part of life for the people of Ensaro district. In total 44 ethnoveterinary medicinal plants were reported to have been used to treat livestock health disorders in the study area. Leaves were the most frequently used parts of medicinal plants in the preparation of traditional remedies. In general, the findings of this study revealed diverse ethnoveterinary medicinal plants and associated indigenous practices about their use in the Ensaro District. It is therefore valuable to conserve these plants. In addition, it is important to carry out antimicrobial activity and toxicity studies on these medicinal plants to build up trust on the community and to develop novel drugs to combat currently appearing new diseases that can not be controlled by already synthesized drugs.

\section{Declarations}

\section{Ethics approval and consent participant}

Permission to conduct the ethnobotanical study was obtained from the district administration and village administrators in the study area. The purpose of the study was explained to all participants, and they agreed to provide information

\section{Funding}

The ministry of higher education, the Ethiopian public health institute, and Debere Berhan University supported this study.

\section{Availability of data and materials}

The authors declare that all other data supporting the findings of this study are available within the article and its supplementary information files.

\section{Competing interest}

The authors have not declared any conflicts of interest.

\section{Authors' contributions}


Asaye Asfaw conceived the idea of doing this research, conducted the interviews, collected samples, outlined and wrote the manuscript. Ermias Lulekal was involved in the identification of collected plant materials and searching for the fund. Asfaw Debella, Eyob Debebe, and Bihonegn Sisay participated in the planning and preparation of semistructured questions. Tamrat Bekele was revising it critically for important intellectual content. All authors have made substantial contributions to the analysis, interpretation of data, and writing of the manuscript. All authors read and approved the final manuscript.

\section{Acknowledgment}

The authors appreciate and express their thanking words to officials of Ensaro woreda who facilitated the study and the community members that participated during the interviews. Without their contribution, this study would have been impossible. The first author thanks the scholarship from Debre Berhan University. EPHI (Ethiopian people's health institute, period 2019/2021) who gave the financial support is acknowledged.

\section{References}

1. Abera, Y., \& Mulate, B. (2019). Ethno-Veterinary Medicine: A Potential Alternative to Animal Health Delivery in Wolmera District, Oromia Region, Ethiopia. Ethiopian Veterinary Journal, 23(1), 111-130.

2. Adeniran, L. A., Okpi, S., Anjorin, T. S., \& Ajagbonna, O. P. (2020). Medicinal Plants Used in Ethnoveterinary Practices in the Federal Capital Territory, North-Central Nigeria. Journal of Medicinal Plants Research, 14(8), 377388.

3. Alebie, G., \& Mehamed, A. (2016). An Ethno-Botanical Study of Medicinal Plants in Jigjiga Town, Capital City of Somali Regional State of Ethiopia. International Journal of Herbal Medicine, 4(6), 168-175.

4. Alexiades, M. N., \& Sheldon, J. W. (1996). Selected Guidelines for Ethnobotanical Research: A Field Manual.

5. Asresie, A., Zemedu, L., \& Adigrat, E. (2015). The Contribution of Livestock Sector in Ethiopian Economy. A Review. Advances in Life Science and Technology, 29, 79-90.

6. Assefa, A., \& Bahiru, A. (2018). Ethnoveterinary Botanical Survey of Medicinal Plants in Abergelle, Sekota and Lalibela Districts of Amhara Region, Northern Ethiopia. Journal of Ethnopharmacology, 213, 340-349.

7. Birhan, Y., Kitaw, S., Alemayehu, Y., \& Mengesha, N. (2018). Ethnoveterinary Medicinal Plants and Practices in Enarj Enawga District, East Gojjam Zone, Amhara Region, Ethiopia. Int J Anim Sci, 2(1), 1014.

8. Birhan, Y. S., Kitaw, S. L., Alemayehu, Y. A., \& Mengesha, N. M. (2017). Ethnobotanical Study of Medicinal Plants Used to Treat Human Diseases in Enarj Enawga District, East Gojjam Zone, Amhara Region, Ethiopia. SM Journal of Medicinal Plant Studies, 1(1), 1-9.

9. Cherinet, A., \& Mekonnen, Z. (2019). Comparing Farmers' Perception of Climate Change and Variability with Historical Climate Data: The Case of Ensaro District, Ethiopia. International Journal of Environmental Sciences \& Natural Resources, 17(4), 114-120.

10. Cochran, W. G. (2007). Sampling Techniques: John Wiley \& Sons.

11. Cotton, C. M., \& Wilkie, P. (1996). Ethnobotany: Principles and Applications: John Wiley \& Sons Chichester.

12. Dzoyem, J. P., Tchuenteu, R. T., Mbarawa, K., Keza, A., Roland, A., Njouendou, A. J., \& Assob, J. C. N. (2020). Ethnoveterinary Medicine and Medicinal Plants Used in the Treatment of Livestock Diseases in Cameroon Ethnoveterinary Medicine (pp. 175-209): Springer.

13. Eshetu, G. R., Dejene, T. A., Telila, L. B., \& Bekele, D. F. (2015). Ethnoveterinary Medicinal Plants: Preparation and Application Methods by Traditional Healers in Selected Districts of Southern Ethiopia. Veterinary world, 8(5), 674. 
14. Feyera, T., Mekonnen, E., Wakayo, B. U., \& Assefa, S. (2017). Botanical Ethnoveterinary Therapies Used by AgroPastoralists of Fafan Zone, Eastern Ethiopia. BMC Veterinary Research, 13(1), 1-11.

15. Friedman, J., Yaniv, Z., Dafni, A., \& Palewitch, D. (1986). A Preliminary Classification of the Healing Potential of Medicinal Plants, Based on a Rational Analysis of an Ethnopharmacological Field Survey among Bedouins in the Negev Desert, Israel. Journal of Ethnopharmacology, 16(2-3), 275-287.

16. Gazzaneo, L. R. S., De Lucena, R. F. P., \& de Albuquerque, U. P. (2005). Knowledge and Use of Medicinal Plants by Local Specialists in an Region of Atlantic Forest in the State of Pernambuco (Northeastern Brazil). Journal of ethnobiology and ethnomedicine, 1(1), 1-8.

17. Giday, M., Asfaw, Z., \& Woldu, Z. (2009). Medicinal Plants of the Meinit Ethnic Group of Ethiopia: An Ethnobotanical Study. Journal of Ethnopharmacology, 124(3), 513-521.

18. Giday, M., \& Teklehaymanot, T. (2013). Ethnobotanical Study of Plants Used in Management of Livestock Health Problems by Afar People of Ada'ar District, Afar Regional State, Ethiopia. Journal of ethnobiology and ethnomedicine, 9(1), 1-10.

19. Gonfa, N., Tulu, D., Hundera, K., \& Raga, D. (2020). Ethnobotanical Study of Medicinal Plants, Its Utilization, and Conservation by Indigenous People of Gera District, Ethiopia. Cogent Food \& Agriculture, 6(1), 1852716.

20. Heinrich, M. (2000). Ethnobotany and Its Role in Drug Development. Phytotherapy Research: An International Journal Devoted to Pharmacological and Toxicological Evaluation of Natural Product Derivatives, 14(7), 479-488.

21. Heinrich, M., Lardos, A., Leonti, M., Weckerle, C., Willcox, M., Applequist, W.,.. . Stafford, G. (2018). Best Practice in Research: Consensus Statement on Ethnopharmacological Field Studies-Consefs. Journal of Ethnopharmacology, 211, 329-339.

22. Kebede, A., Ayalew, S., Mesfin, A., \& Mulualem, G. (2017). An Ethnoveterinary Study of Medicinal Plants Used for the Management of Livestock Ailments in Selected Kebeles of Dire Dawa Administration, Eastern Ethiopia. Journal of Plant Sciences, 5(1), 34-42.

23. Khan, K., Rahman, I. U., Calixto, E. S., Ali, N., \& ljaz, F. (2019). Ethnoveterinary Therapeutic Practices and Conservation Status of the Medicinal Flora of Chamla Valley, Khyber Pakhtunkhwa, Pakistan. Frontiers in veterinary science, 6, 122.

24. Kidane, L., Gebremedhin, G., \& Beyene, T. (2018). Ethnobotanical Study of Medicinal Plants in Ganta Afeshum District, Eastern Zone of Tigray, Northern Ethiopia. Journal of ethnobiology and ethnomedicine, 14(1), 1-19.

25. Lulekal, E., Asfaw, Z., Kelbessa, E., \& Van Damme, P. (2013). Ethnomedicinal Study of Plants Used for Human Ailments in Ankober District, North Shewa Zone, Amhara Region, Ethiopia. Journal of ethnobiology and ethnomedicine, 9(1), 1-13.

26. Lulekal, E., Asfaw, Z., Kelbessa, E., \& Van Damme, P. (2014). Ethnoveterinary Plants of Ankober District, North Shewa Zone, Amhara Region, Ethiopia. Journal of ethnobiology and ethnomedicine, 10(1), 1-19.

27. Mahmoud, A. D., Fatihah, H. N. N., Khandaker, M. M., Ali, A. M., \& Mat, N. (2020). Ethnobotany of Syzygium Polyanthum (Wight) Walp in Terengganu, Peninsular Malaysia. Journal Of Agrobiotechnology, 11(2), 39-47.

28. Martin, G. (1995). Ethnobotany-a Manual of Methods. London: Chapman et Hall.

29. Maryo, M., Nemomissa, S., \& Bekele, T. (2015). An Ethnobotanical Study of Medicinal Plants of the Kembatta Ethnic Group in Enset-Based Agricultural Landscape of Kembatta Tembaro (Kt) Zone, Southern Ethiopia. Asian $J$ Plant Sci Res, 5(7), 42-61.

30. McCorkle, C. M., \& Green, E. C. (1998). Intersectoral Healthcare Delivery. Agriculture and Human values, 15(2), 105-114. 
31. Megersa, M., Asfaw, Z., Kelbessa, E., Beyene, A., \& Woldeab, B. (2013). An Ethnobotanical Study of Medicinal Plants in Wayu Tuka District, East Welega Zone of Oromia Regional State, West Ethiopia. Journal of ethnobiology and ethnomedicine, 9(1), 1-18.

32. Njoroge, G. N., \& Bussmann, R. W. (2006). Herbal Usage and Informant Consensus in Ethnoveterinary Management of Cattle Diseases among the Kikuyus (Central Kenya). Journal of Ethnopharmacology, 108(3), 332-339.

33. Shapiro, B. I., Gebru, G., Desta, S., Negassa, A., Nigussie, K., Aboset, G., \& Mechale, H. (2017). Ethiopia Livestock Sector Analysis: A 15 Year Livestock Sector Strategy.

34. Tamiru, F., Terfa, W., Kebede, E., Dabessa, G., Roy, R. K., \& Sorsa, M. (2013). Ethnoknowledge of Plants Used in Veterinary Practices in Dabo Hana District, West Ethiopia. Journal of Medicinal Plants Research, 7(40), 29602971.

35. Tardío, J., \& Pardo-de-Santayana, M. (2008). Cultural Importance Indices: A Comparative Analysis Based on the Useful Wild Plants of Southern Cantabria (Northern Spain). Economic Botany, 62(1), 24-39.

36. Tekle, Y. (2015). Medicinal Plants in the Ethno Veterinary Practices of Bensa Woreda, Southern Ethiopia. Open Access Library Journal, 2(01), 1.

37. Tesfaye, M., \& Erena, M. G. (2020). Indigenous Ethnozoological and Ethnoveterinary Medicinal Practices in Leka Dullecha District, Western Ethiopia.

38. Tonamo, A. (2016). A Review on Cattle Husbandry Practices in Ethiopia. International Journal of Livestock Production, 7(2), 5-11.

39. Trotter, R. T., \& Logan, M. H. (1986). Informant Consensus: A New Approach for Identifying Potenially Effective Medicinal Plants.

40. Tufa, T. B., Gurmu, F., Beyi, A. F., Hogeveen, H., Beyene, T. J., Ayana, D.,.. . Stegeman, J. (2018). Veterinary Medicinal Product Usage among Food Animal Producers and Its Health Implications in Central Ethiopia. BMC Veterinary Research, 14(1), 1-7.

41. Vitalini, S., Iriti, M., Puricelli, C., Ciuchi, D., Segale, A., \& Fico, G. (2013). Traditional Knowledge on Medicinal and Food Plants Used in Val San Giacomo (Sondrio, Italy)-an Alpine Ethnobotanical Study. Journal of Ethnopharmacology, 145(2), 517-529.

42. Weckerle, C. S., de Boer, H. J., Puri, R. K., van Andel, T., Bussmann, R. W., \& Leonti, M. (2018). Recommended Standards for Conducting and Reporting Ethnopharmacological Field Studies. Journal of Ethnopharmacology, $210,125-132$.

43. WHO. (2002). Traditional Medicine: Growing Needs and Potential. Retrieved from

44. Wodegebriel, Y. W., Abebe, B. F., \& Tamir, A. (2018). Medicinal Plants Used by Farmers for Treatment of Major Diseases of Chicken in South Wollo Zone, Amhara Region, Ethiopia. Int. J. Adv. Res. Biol. Sci, 5(10), 45-58.

45. Yami, M., Begna, B., \& Teklewold, T. (2013). Enhancing the Productivity of Livestock Production in Highland of Ethiopia: Implication for Improved on-Farm Feeding Strategies and Utilization. International Journal of Livestock Production, 4(8), 113-127.

46. Yigezu, Y., Haile, D. B., \& Ayen, W. Y. (2014). Ethnoveterinary Medicines in Four Districts of Jimma Zone, Ethiopia: Cross Sectional Survey for Plant Species and Mode of Use. BMC Veterinary Research, 10(1), 1-12.

47. Yineger, H., Kelbessa, E., Bekele, T., \& Lulekal, E. (2007). Ethnoveterinary Medicinal Plants at Bale Mountains National Park, Ethiopia. Journal of Ethnopharmacology, 112(1), 55-70.

48. Yineger, H., \& Yewhalaw, D. (2007). Traditional Medicinal Plant Knowledge and Use by Local Healers in Sekoru District, Jimma Zone, Southwestern Ethiopia. Journal of ethnobiology and ethnomedicine, 3(1), 1-7. 
49. Yineger, H., Yewhalaw, D., \& Teketay, D. (2008). Plants of Veterinary Importance in Southwestern Ethiopia: The Case of Gilgel Ghibe Area. Forests, Trees and Livelihoods, 18(2), 165-181.

50. Yirga, G., Teferi, M., Gidey, G., \& Zerabruk, S. (2012). An Ethnoveterinary Survey of Medicinal Plants Used to Treat Livestock Diseases in Seharti-Samre District, Northern Ethiopia. African Journal of Plant Science, 6(3), 113-119.

\section{Figures}
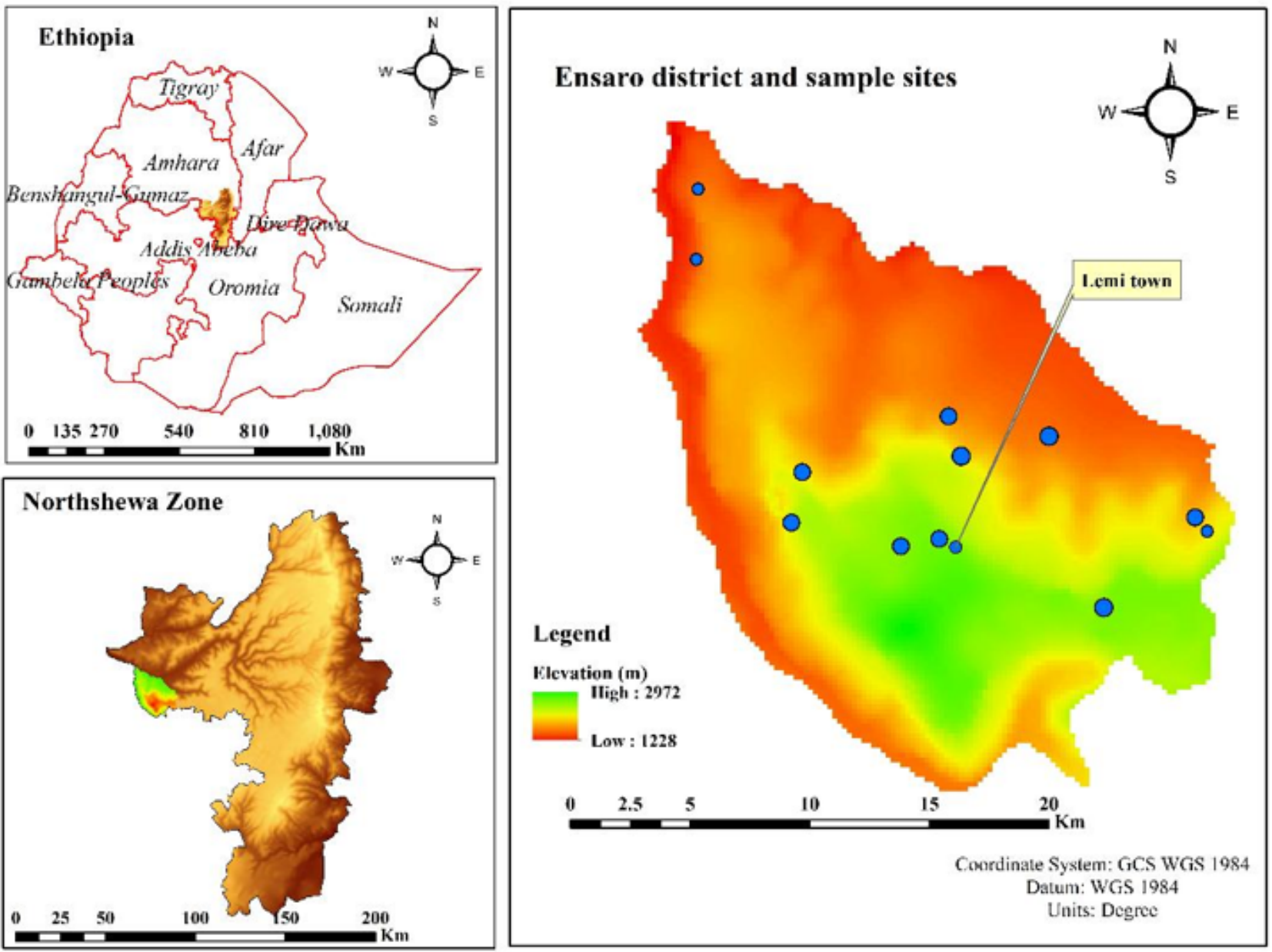

Figure 1

Map of Ethiopia showing Amhara Region and the study district 


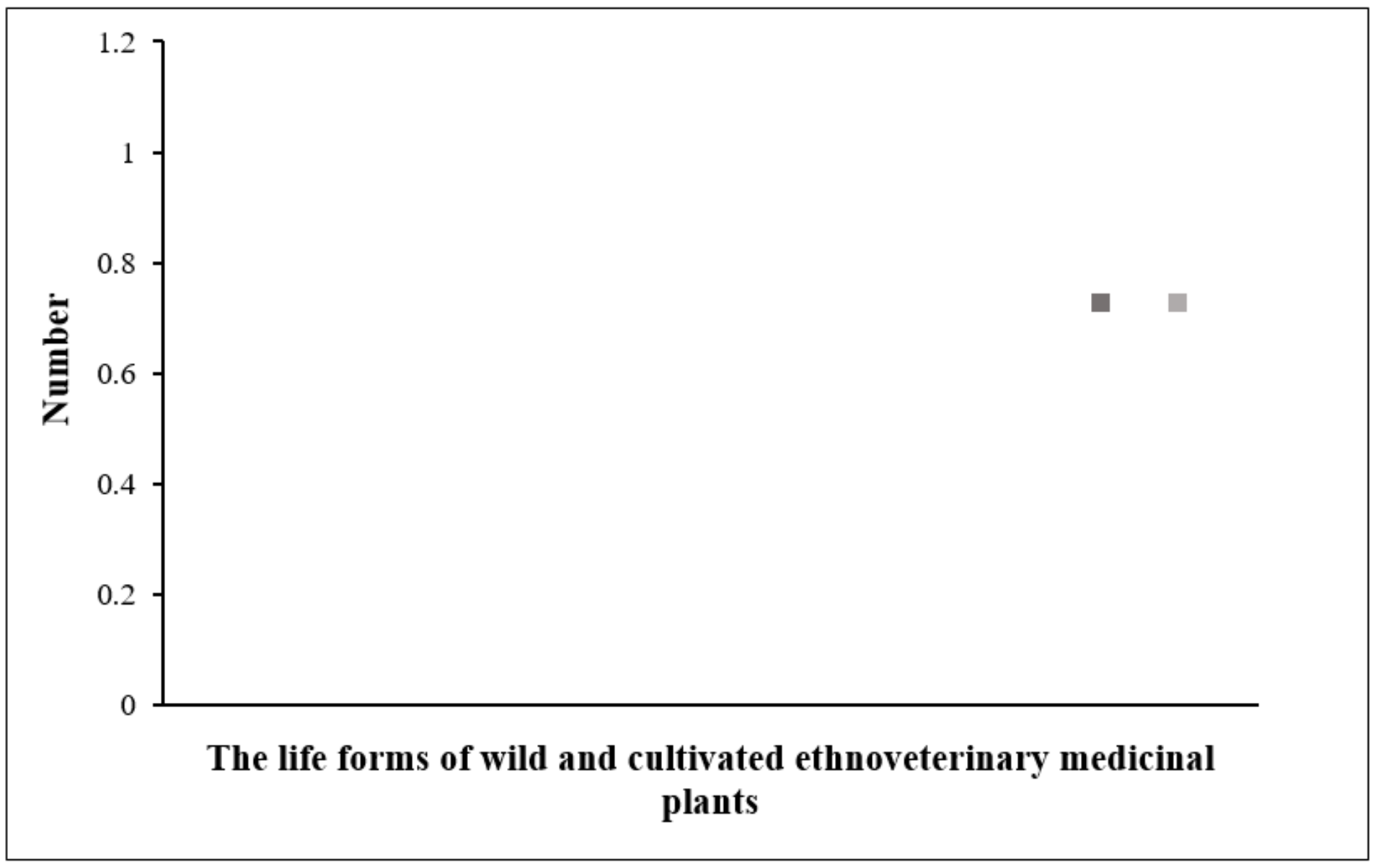

\section{Figure 2}

The life forms of wild and cultivated ethnoveterinary medicinal plants 


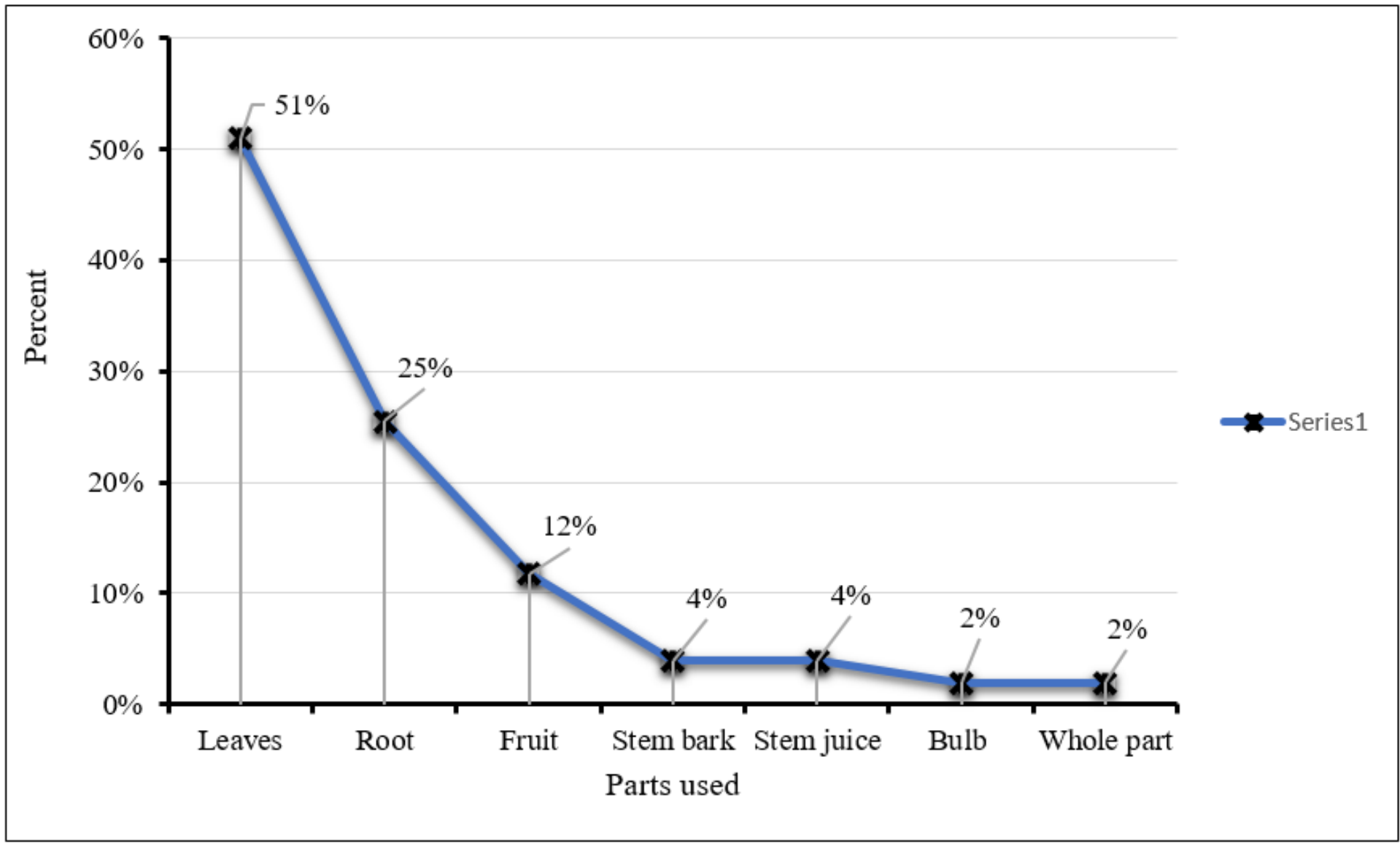

Figure 3

Medicinal plant parts used to prepare traditional medicines in Ensaro district

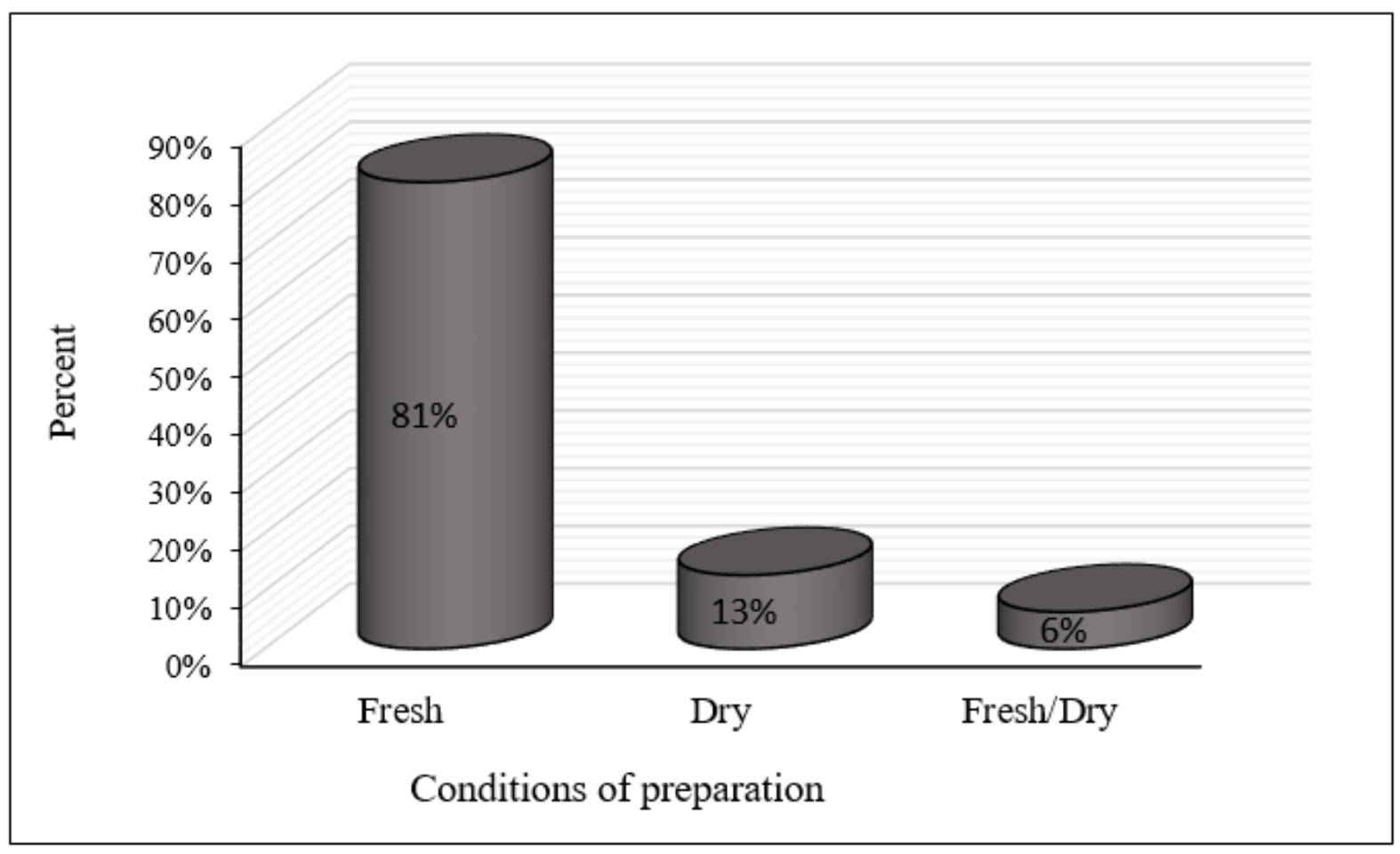

Figure 4 


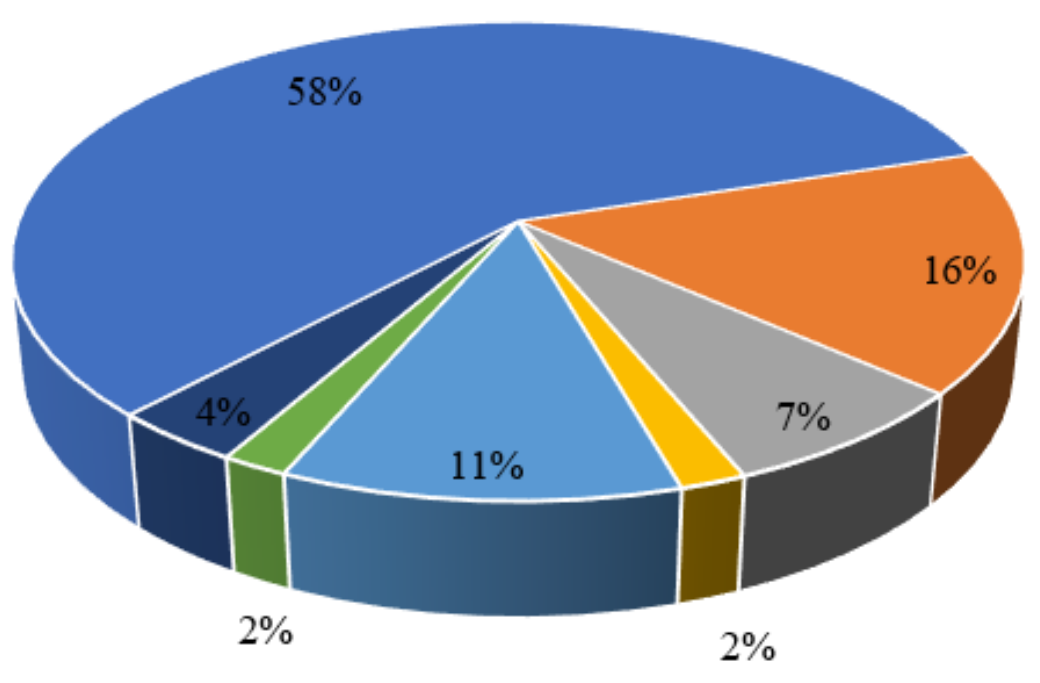

- Drenching

- Dropping

- Eating

- Fumigation

- smearing

- Washing

- Wrapping

\section{Figure 5}

Methods of plant medicine applications in Ensaro District. Types and percentages of traditional plant medicines applications

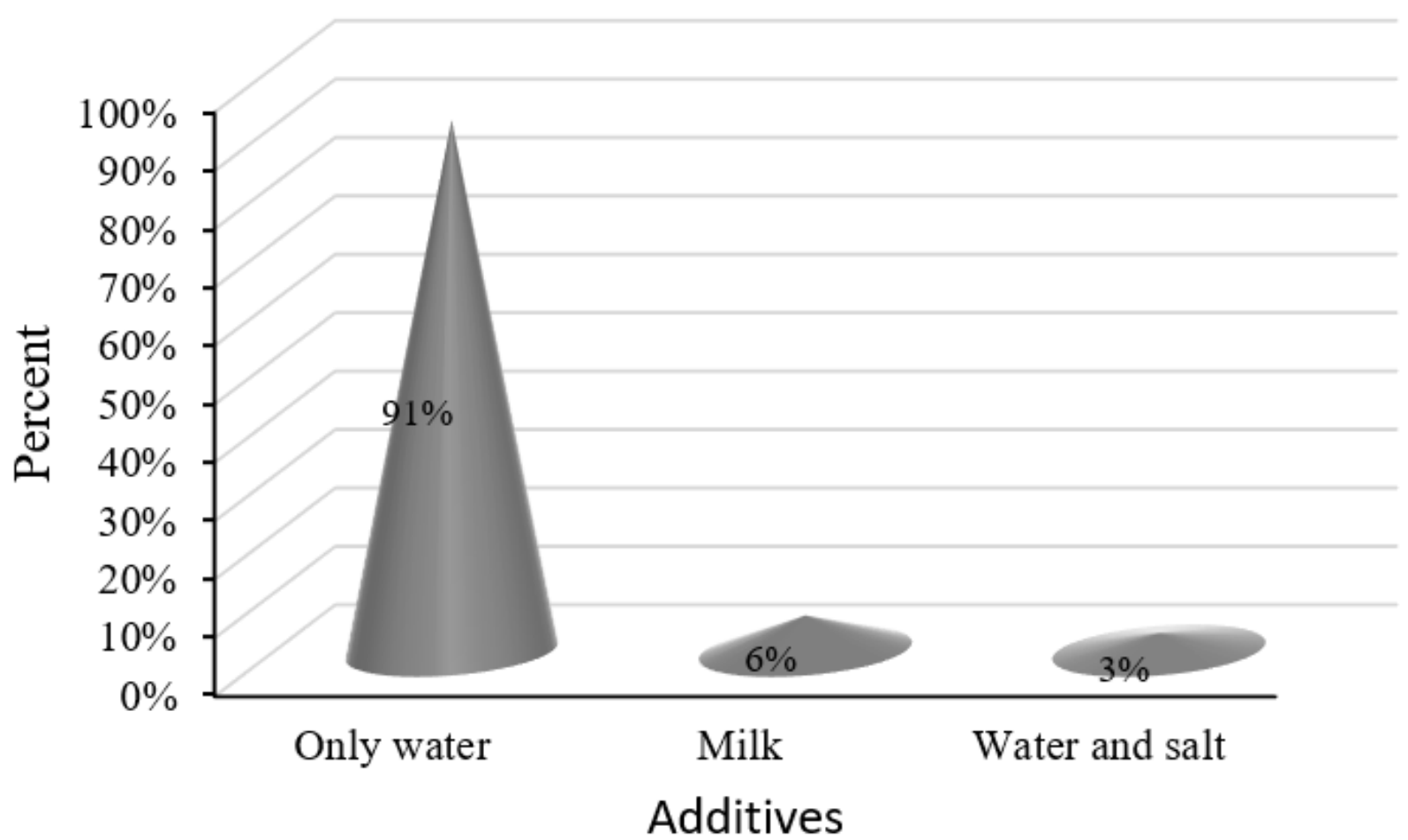

Figure 6

Ingredients added during remedy preparations 


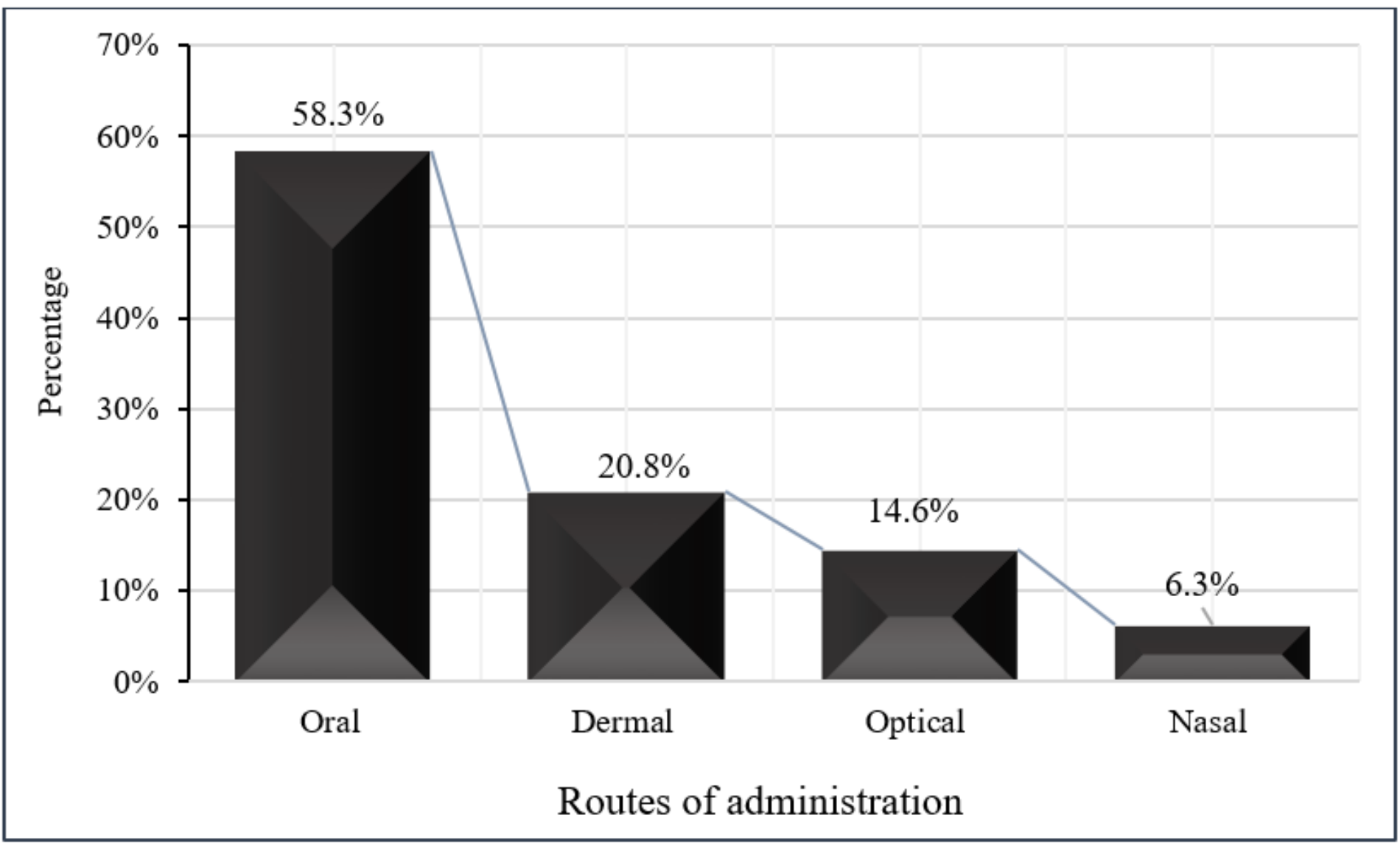

Figure 7

Routes of administration of traditional plant medicines.

\section{Supplementary Files}

This is a list of supplementary files associated with this preprint. Click to download.

- Families.xlsx

- Speciesandhabit.xlsx

- Appendix.docx 